Article

\title{
Application of the Fractal Dimension Calculation Technique to Determine the Shape of Selected Monchepluton Intrusion Crystals (NE Fennoscandia)
}

\author{
Miłosz Huber* and Klaudia Stępniewska \\ Geology, Soil Science and Geoinformacy Department, Earth Science and Spatial Management Faculty, \\ Maria Curie-Skłodowska University, 20-718 Lublin, Poland; klauu15@op.pl \\ * Correspondence: milosz.huber@mail.umcs.pl; Tel.: +48-81-537-6800
}

check for

updates

Citation: Huber, M.; Stępniewska, K. Application of the Fractal Dimension Calculation Technique to Determine the Shape of Selected Monchepluton Intrusion Crystals (NE Fennoscandia). Minerals 2021, 11, 1140. https:/ / doi.org/10.3390/min11101140

Academic Editor:

Maria Economou-Eliopoulos and Sytle M. Antao

Received: 27 July 2021

Accepted: 11 October 2021

Published: 17 October 2021

Publisher's Note: MDPI stays neutral with regard to jurisdictional claims in published maps and institutional affiliations.

Copyright: (c) 2021 by the authors. Licensee MDPI, Basel, Switzerland. This article is an open access article distributed under the terms and conditions of the Creative Commons Attribution (CC BY) license (https:/ / creativecommons.org/licenses/by/ $4.0 /)$.

\begin{abstract}
Thirty-eight samples of minerals from Paleoproterozoic Layered PGE Intrusion Monchepluton, located in NE Fennoscandia, were tested. An automated computational technique was used which involved counting the sides superimposed on vectorized graphics using separated crystal boundaries. The results were obtained for olivine, orthopyroxene, clinopyroxene, and plagioclase. On this basis, an interpretation of the mineral box fractal dimension was made, along with an interpretation of its nature in the rock in which it was found. The performed calculations were applied to the sampling positions, and maps of changes in fractal dimensions were prepared. The nature of the minerals studied was correlated with the type of rocks present in Monchepluton. Then, the fractal dimensions were scaled to a percentage scale determining the mean value for the euhedral crystal as $100 \%$, and a map was obtained representing the advancement of secondary processes after summing these data for all four investigated minerals. This method was analyzed and its advantages and limitations shown.
\end{abstract}

Keywords: fractal dimension; rock-forming minerals; Monchepluton; NE Fennoscandia

\section{Introduction}

Descriptions of structure and texture are indispensable for our knowledge of rocks. Based on these descriptions, inferences can be made about which phase is older and which is more recent, which is subject to corrosion and which is regenerating. The determination of the nature and size of a mineral and its position relative to other phases provides evidence for the processes of rock formation. This is especially important in the case of rock-forming minerals, the presence and nature of which are of great importance for the correct understanding of rock genesis and secondary processes. Observations of the degree of formation of the shape of the mineral are significantly related to an understanding of its crystallization and what happened to the mineral after its formation. However, modern petrography has many different names for mineral structures and textures, and the particular terms used to define the shape of a mineral are basically dependent on the imagination of the person describing it and may not be so obvious to another person looking at the same mineral. Moreover, it is not possible to compare the different terms that are used in a strict sense. The methods of fractal analysis, which repetitively and accurately describe the nature of the crystal boundary, allow you to compare results and indicate the ways in which minerals differ from one another, thereby providing a means of overcoming this problem. As a science, fractal analysis is currently developing at a relatively rapid rate. In geology, fractal analyses are typically used for the assessment of rock porosity, the study of soil granularity [1-5], geophysical analyses, analysis of reservoirs [6,7], tectonics [8], and textural studies of rocks [9-12]. In the case of digitization, the techniques for determining the crystals boundaries, in the petrographic analyses are much less well developed. However, the advancement of computational techniques means that significant progress is being made here as well. 
This study aims to investigate and interpret the fractal dimension of rock-forming minerals in the Paleoproterozoic Platinum Group Elements (PGE) of Monchepluton's Layered Intrusion.

Monchepluton is located in NE Fennoscandia, in the area of the Kola (Figure 1) [13-15]. It is composed of two arms situated more or less latitudinally and longitudinally. In the meridian arm, there are the massifs (from the north) Traviannaya, Kumuzhia, and Nittis (NKT), and in the latitudinal (from the west) Sopcha, Nyud, and Poaz. In the NKT massifs, there are rocks made of dunites, harzburgites, accompanied by chromitite ore, and orthopyroxenite. In Sopcha, there are orthopyroxenites, Nyud-norites, and Poaz gabbronorites, while a slight admixture of plagioclases is already visible in the Sopcha massif (Figure 1). The age of this intrusion is estimated at 2.5 billion years [16-18] and is characterized by a multi-stage crystallization of rock-forming minerals, combined with an injection of magma [19-22]. After the crystallization period, several secondary processes took place, including the local metamorphism of these rocks $[23,24]$, which resulted in visible changes in the rocks belonging to the mentioned intrusion.

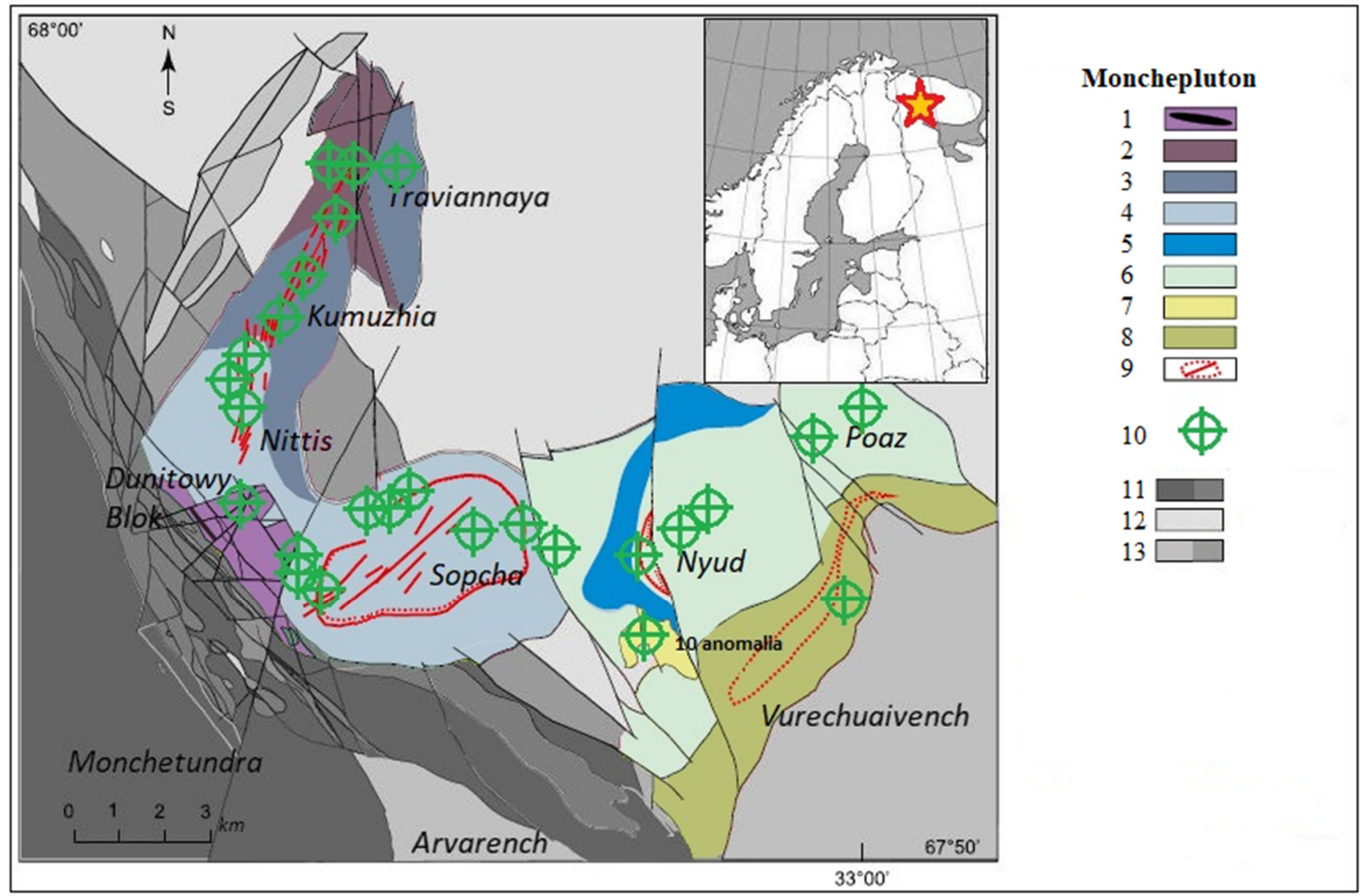

Figure 1. Schematic sketch of the Monchepluton intrusion (according to Mitrofanov and Smolkin [25], simplified by the author) with the location of the tested samples. Legend: (1) dunite, chromitite; (2) harzburgite; (3) other peridotites; (4) orthopyroxenite; (5) norite, olivine norite; (6) gabbronorite; (7) gabbro; (8) anorthosite; (9) sulfide ore mineralization; (10) samples localization; (11) rocks of the Monchetudra massif; (12) rocks of the Imandra-Varzuga Belt; (13) rocks of the Kola Series. The red-orange star in the map inset, symbolizes the location of the intrusion on the Scandinavian background.

These processes affected the textures of the rocks. Rock-forming minerals, such as pyroxenes, olivines, and plagioclases, crystallized under various conditions, some of them showing signs of corrosion. The diverse shape of these minerals reflects the processes that took place in the rocks in question. Precise tracking of these changes within the discussed intrusion is necessary for determining the advancement of secondary processes. This can be done with the help of fractal analysis of individual rock-forming minerals [20,26,27]. 


\section{Materials and Methods}

To perform fractal calculations, rock samples were selected from which thin plate preparations were made (Table 1, Figure 1). These preparations were photographed using the Leica DM2500P optical polarizing microscope at the Department of Geology, Soil Science, and Geoinformation at the Maria Curie-Skłodowska University in Lublin. Then, from the obtained micrographs, rock-forming minerals such as olivine, orthopyroxene, clinopyroxene, and plagioclase were selected. Further calculations were made using QGIS (Version 3.18.3 'Zurich', Open Source Geospatial Foundation, Beaverton, OR, USA) and MS Excel software (Figure 2A). The principle of the method used is as follows: after importing the photomicrographs to QGIS, a vector map was created, simultaneously separating the background (black) from the calculated area (Figure 2B). Then, the boundaries of the studied crystals were separated, and the area was cut into individual shapes corresponding to the selected minerals and labeled (Figure 2C). These boundaries were delineated based on changes in the optical characteristics of the minerals, e.g., color. Then, a selection was made of the beans to be further processed (Figure 2D). The next step was to create a grid of squares with a given side length (Figure 2E) and filter the tested grains in each square grid (Figure 2E).

Table 1. Location of samples from the Monchepluton massif used for fractal analysis.

\begin{tabular}{|c|c|c|c|c|c|c|c|}
\hline Sample & Massif & Latitude & Longitude & Sample & Massif & Latitude & Longitude \\
\hline 46MON17 & Dunite Block & $67^{\circ} 53^{\prime} 57.4^{\prime \prime} \mathrm{N}$ & $32^{\circ} 45^{\prime} 59.0^{\prime \prime} \mathrm{E}$ & 32MON19 & Sopcha N & $67^{\circ} 53^{\prime} 36.30^{\prime \prime} \mathrm{N}$ & $32^{\circ} 48^{\prime} 53.32^{\prime \prime} \mathrm{E}$ \\
\hline 02MON19 & Dunite Block & $67^{\circ} 53^{\prime} 49.09^{\prime \prime} \mathrm{N}$ & $32^{\circ} 44^{\prime} 57.01^{\prime \prime} \mathrm{E}$ & 39MON19 & Sopcha N & $67^{\circ} 53^{\prime} 36.31^{\prime \prime} \mathrm{N}$ & $32^{\circ} 48^{\prime} 53.35^{\prime \prime} \mathrm{E}$ \\
\hline 56MON17 & Dunite Block & $67^{\circ} 53^{\prime} 57.4^{\prime \prime} \mathrm{N}$ & $32^{\circ} 45^{\prime} 59.0^{\prime \prime} \mathrm{E}$ & 40MON19 & Sopcha N & $67^{\circ} 53^{\prime} 36.32^{\prime \prime} \mathrm{N}$ & $32^{\circ} 48^{\prime} 53.38^{\prime \prime} \mathrm{E}$ \\
\hline 67MON17 & Traviannaya & $67^{\circ} 56^{\prime} 33.0^{\prime \prime} \mathrm{N}$ & $32^{\circ} 49^{\prime} 03.3^{\prime \prime} \mathrm{E}$ & $38 \mathrm{MON} 16$ & Sopcha W & $67^{\circ} 53^{\prime} 29.7^{\prime \prime} \mathrm{N}$ & $32^{\circ} 49^{\prime} 59.1^{\prime \prime} \mathrm{E}$ \\
\hline 01MON19 & Traviannaya & $67^{\circ} 56^{\prime} 38.15^{\prime \prime} \mathrm{N}$ & $32^{\circ} 48^{\prime} 40.18^{\prime \prime} \mathrm{E}$ & 39MON16 & Sopcha W & $67^{\circ} 53^{\prime} 33.7^{\prime \prime} \mathrm{N}$ & $32^{\circ} 50^{\prime} 03.4^{\prime \prime} \mathrm{E}$ \\
\hline 07MON18 & Traviannaya & $67^{\circ} 56^{\prime} 38.2^{\prime \prime} \mathrm{N}$ & $32^{\circ} 48^{\prime} 40.2^{\prime \prime} \mathrm{E}$ & 42MON16 & Sopcha W & $67^{\circ} 53^{\prime} 40.5^{\prime \prime} \mathrm{N}$ & $32^{\circ} 50^{\prime} 11.0^{\prime \prime} \mathrm{E}$ \\
\hline 84MON17 & Traviannaya & $67^{\circ} 56^{\prime} 32.4^{\prime \prime} \mathrm{N}$ & $32^{\circ} 48^{\prime} 08.3^{\prime \prime} \mathrm{E}$ & 43MON16 & Sopcha W & $67^{\circ} 53^{\prime} 40.52^{\prime \prime} \mathrm{N}$ & $32^{\circ} 50^{\prime} 11.05^{\prime \prime} \mathrm{E}$ \\
\hline 03MON19 & Kumuzhia & $67^{\circ} 55^{\prime} 44.3^{\prime \prime} \mathrm{N}$ & $32^{\circ} 48^{\prime} 03.9^{\prime \prime} \mathrm{E}$ & 44MON16 & Sopcha W & $67^{\circ} 53^{\prime} 49.5^{\prime \prime} \mathrm{N}$ & $32^{\circ} 49^{\prime} 54.6^{\prime \prime} \mathrm{E}$ \\
\hline 04MON19 & Kumuzhia & $67^{\circ} 55^{\prime} 45,55^{\prime \prime} \mathrm{N}$ & $32^{\circ} 47^{\prime} 29.51^{\prime \prime} \mathrm{E}$ & 45MON16 & Sopcha W & $67^{\circ} 53^{\prime} 49.51^{\prime \prime} \mathrm{N}$ & $32^{\circ} 49^{\prime} 54.63^{\prime \prime} \mathrm{E}$ \\
\hline 05MON19 & Kumuzhia & $67^{\circ} 55^{\prime} 45,54^{\prime \prime} \mathrm{N}$ & $32^{\circ} 47^{\prime} 29.53^{\prime \prime} \mathrm{E}$ & 08MON17 & Nyud & $67^{\circ} 53^{\prime} 11.3^{\prime \prime} \mathrm{N}$ & $32^{\circ} 53^{\prime} 57.3^{\prime \prime} \mathrm{E}$ \\
\hline 07MON19 & Kumuzhia & $67^{\circ} 55^{\prime} 50.88^{\prime \prime} \mathrm{N}$ & $32^{\circ} 47^{\prime} 26.16^{\prime \prime} \mathrm{E}$ & 09MON17 & Nyud & $67^{\circ} 53^{\prime} 11.3^{\prime \prime} \mathrm{N}$ & $32^{\circ} 53^{\prime} 57.3^{\prime \prime} \mathrm{E}$ \\
\hline 18MON19 & Nittis & $67^{\circ} 55^{\prime} 05.48^{\prime \prime} \mathrm{N}$ & $32^{\circ} 45^{\prime} 32.88^{\prime \prime} \mathrm{E}$ & 14MON17 & Nyud & $67^{\circ} 53^{\prime} 29.15^{\prime \prime} \mathrm{N}$ & $32^{\circ} 54^{\prime} 48.02^{\prime \prime} \mathrm{E}$ \\
\hline 29MON17 & Sopcha E & $67^{\circ} 53^{\prime} 09.2^{\prime \prime} \mathrm{N}$ & $32^{\circ} 52^{\prime} 48.6^{\prime \prime} \mathrm{E}$ & 15MON17 & Nyud & $67^{\circ} 53^{\prime} 29.2^{\prime \prime} \mathrm{N}$ & $32^{\circ} 54^{\prime} 48.1^{\prime \prime} \mathrm{E}$ \\
\hline 30MON17 & Sopcha E & $67^{\circ} 53^{\prime} 09.2^{\prime \prime} \mathrm{N}$ & $32^{\circ} 52^{\prime} 48.6^{\prime \prime} \mathrm{E}$ & 16MON17 & Nyud & $67^{\circ} 53^{\prime} 31.7^{\prime \prime} \mathrm{N}$ & $32^{\circ} 54^{\prime} 55.7^{\prime \prime} \mathrm{E}$ \\
\hline 31MON17 & Sopcha E & $67^{\circ} 53^{\prime} 09.24^{\prime \prime} \mathrm{N}$ & $32^{\circ} 52^{\prime} 48.6^{\prime \prime} \mathrm{E}$ & 20MON17 & Nyud & $67^{\circ} 53^{\prime} 31.75^{\prime \prime} \mathrm{N}$ & $32^{\circ} 54^{\prime} 55.77^{\prime \prime} \mathrm{E}$ \\
\hline 32MON17 & Sopcha E & $67^{\circ} 53^{\prime} 09.25^{\prime \prime} \mathrm{N}$ & $32^{\circ} 52^{\prime} 48.6^{\prime \prime} \mathrm{E}$ & 22MON17 & Nyud & $67^{\circ} 53^{\prime} 38.3^{\prime \prime} \mathrm{N}$ & $32^{\circ} 55^{\prime} 21.1^{\prime \prime} \mathrm{E}$ \\
\hline $34 \mathrm{MON} 17$ & Sopcha E & $67^{\circ} 53^{\prime} 23.3^{\prime \prime} \mathrm{N}$ & $32^{\circ} 52^{\prime} 05.1^{\prime \prime} \mathrm{E}$ & 24MON17 & Nyud & $67^{\circ} 53^{\prime} 38.2^{\prime \prime} \mathrm{N}$ & $32^{\circ} 55^{\prime} 22.4^{\prime \prime} \mathrm{E}$ \\
\hline 38MON17 & Sopcha E & $67^{\circ} 53^{\prime} 41.7^{\prime \prime} \mathrm{N}$ & $32^{\circ} 51^{\prime} 17.2^{\prime \prime} \mathrm{E}$ & 58MON17 & Poaz & $67^{\circ} 54^{\prime} 58.5^{\prime \prime} \mathrm{N}$ & $32^{\circ} 58^{\prime} 36.0^{\prime \prime} \mathrm{E}$ \\
\hline 31MON19 & Sopcha N & $67^{\circ} 53^{\prime} 36.30^{\prime \prime} \mathrm{N}$ & $32^{\circ} 48^{\prime} 53.30^{\prime \prime} \mathrm{E}$ & 61MON17 & Poaz & $67^{\circ} 54^{\prime} 56.5^{\prime \prime} \mathrm{N}$ & $32^{\circ} 58^{\prime} 20.5^{\prime \prime} \mathrm{E}$ \\
\hline
\end{tabular}

When the square size is small, the boundary display size has an influence on the statistical results, and when the crystal area is small, the influence is particularly obvious; therefore, if possible, it is worth choosing large minerals. The obtained number of squares through which the mineral border passes was set aside to the formula (1) [27]:

$$
\mathrm{D}=\frac{\log _{\mathrm{x} 2}-\log _{\mathrm{x} 1}}{\log _{\mathrm{d} 2}-\log _{\mathrm{d} 1}}
$$

where $\mathrm{x}_{1}$ and $\mathrm{x}_{2}$ correspond to the number of passes of the individual squares $\mathrm{x}_{1}$, and $\mathrm{x}_{2}$ of the contour of the shape, with $\mathrm{d}_{1}$, and $\mathrm{d}_{2}$ of their respective side lengths. 

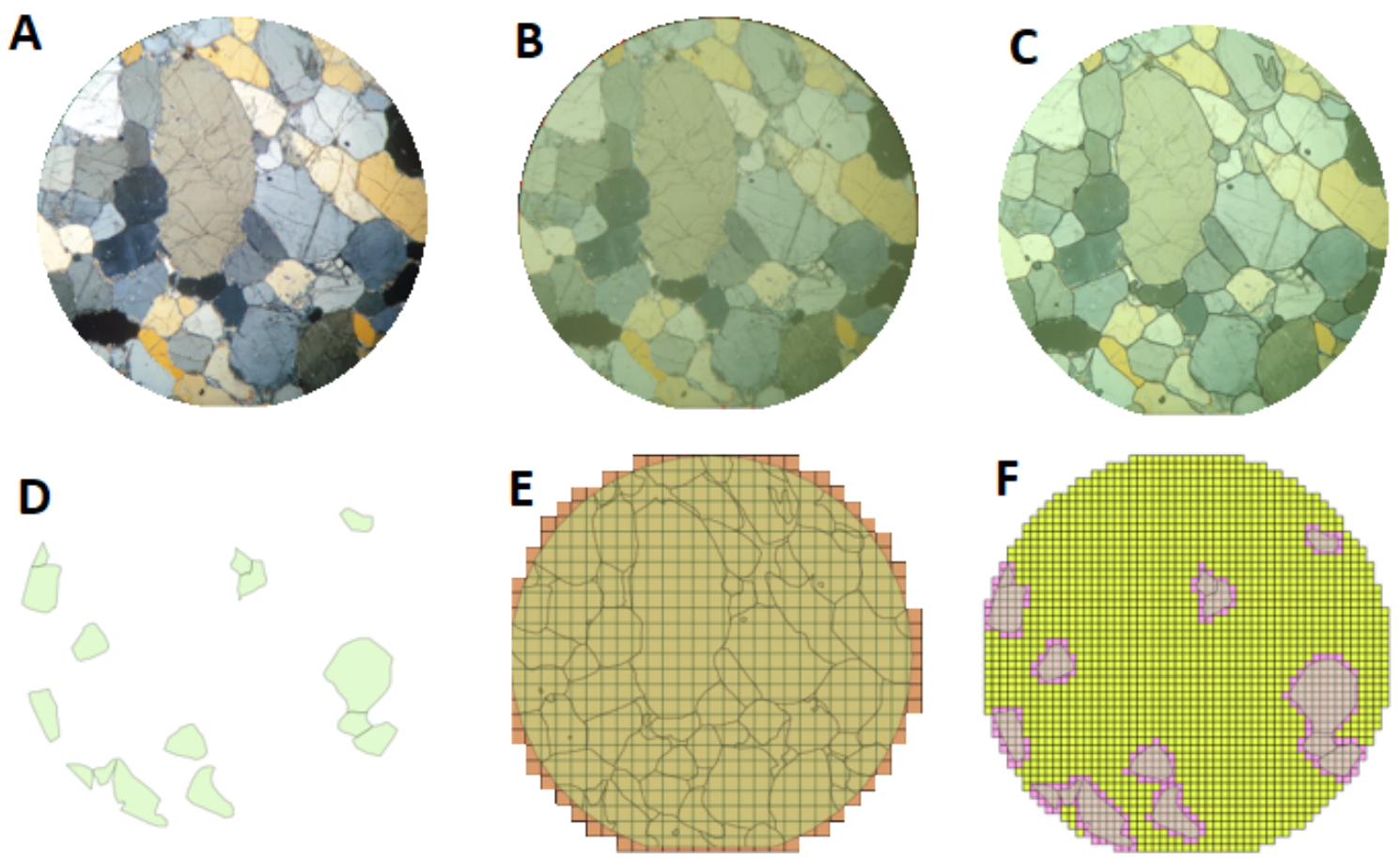

Figure 2. Example of counting crystal boundary contour process: image taken from the microscope camera (A), marking the field of the study area (B), sharpening the boundaries of the crystals (C), identifying and selecting the mineral crystals for analysis (D), applying a grid for counts (E), determining those grid areas that form the boundaries of the selected crystals (F).

After averaging (repeating calculations with different mesh sizes), the result obtained using formula (1) means a fractal dimension that defines the nature of the mineral boundary. When analyzing the results of various shapes, it should be noted that in the case of the box fractal dimension, the result corresponds to the ratio of the shape boundary length to its size. These calculations show that the circle has the smallest box size, the square a larger box size, and the complex figure has the largest. This dimension is a numerical representation and depends on the shape of the object boundary. However, it does not depend on the direction in which this shape changes.

\section{Results}

\subsection{Monchepluton Petrography}

Thirty-eight samples from Monchepluton were selected. Each of the trials discussed was assigned a map (Figure 4, Table 1). These are samples of dunites, harzburgites, and orthopyroxenites from the NKT massif and Sopcha, as well as gabbronorites, olivine gabbronorites, and burrows from the Nyud and Poaz massifs. There are rocks in Dunite Block, the main ingredients of which are olivine and chromite. Dunites (52MON17) have a greenish color, a coarse-crystalline structure, and a compact, random texture. They are composed (Figure 3A) of large oblongs, in contact with each other by olivine crystals, usually strongly serpentine, and accompanied by chromite. In this rock, talc crystals are also visible, and sometimes so too are small individual crystals of orthopyroxene. In these rocks, the proportion of chromite may increase significantly, creating overlapping accumulations of chromitite, creating a compact layered complex. Chromitites (sample $46 \mathrm{MON} 17$ ) are graphite-dark rocks with a coarse crystalline structure, dense, with a random texture, made of chromite, accompanied by inferior olivine and orthopyroxene. Chromite is twinned; it creates accumulations of contacting crystals, between which olivine and orthopyroxene are present. Olivines are highly serpentinized; talc and carbonates coexist with them. The rock exhibits alternating accumulations with femic minerals creating its layered character. In some rocks on the boundary zone, apart from these minerals, 
there are single crystals of orthopyroxene and clinopyroxene, accompanied by plagioclase (02MON19). These rocks have a dark green-gray color, a coarse crystalline structure, are porous, and have an ophthalmic texture. Plagioclase minerals show polysynthetic twins, their shape is diversified, indicating secondary crystallization in the space between melanocratic minerals. Orthocumulus is represented by olivines, often bearing traces of advanced corrosion, surrounded by reactive crowns made of chlorites, serpentine, and talc. In addition to olivines, orthopyroxene crystals are visible, constituting the dominant proportion of femic minerals in the rock. These minerals form accumulations of individuals in contact with each other, but occasionally also exhibit corrosion due to the visible sinus shape of the minerals. In the interstices between these minerals, clinopyroxene is crystallized and usually has a highly developed shape. There are also lines made of talcum powder in the rock. Ore minerals usually appear in the form of small magnetic sprays in the vicinity of olivine.
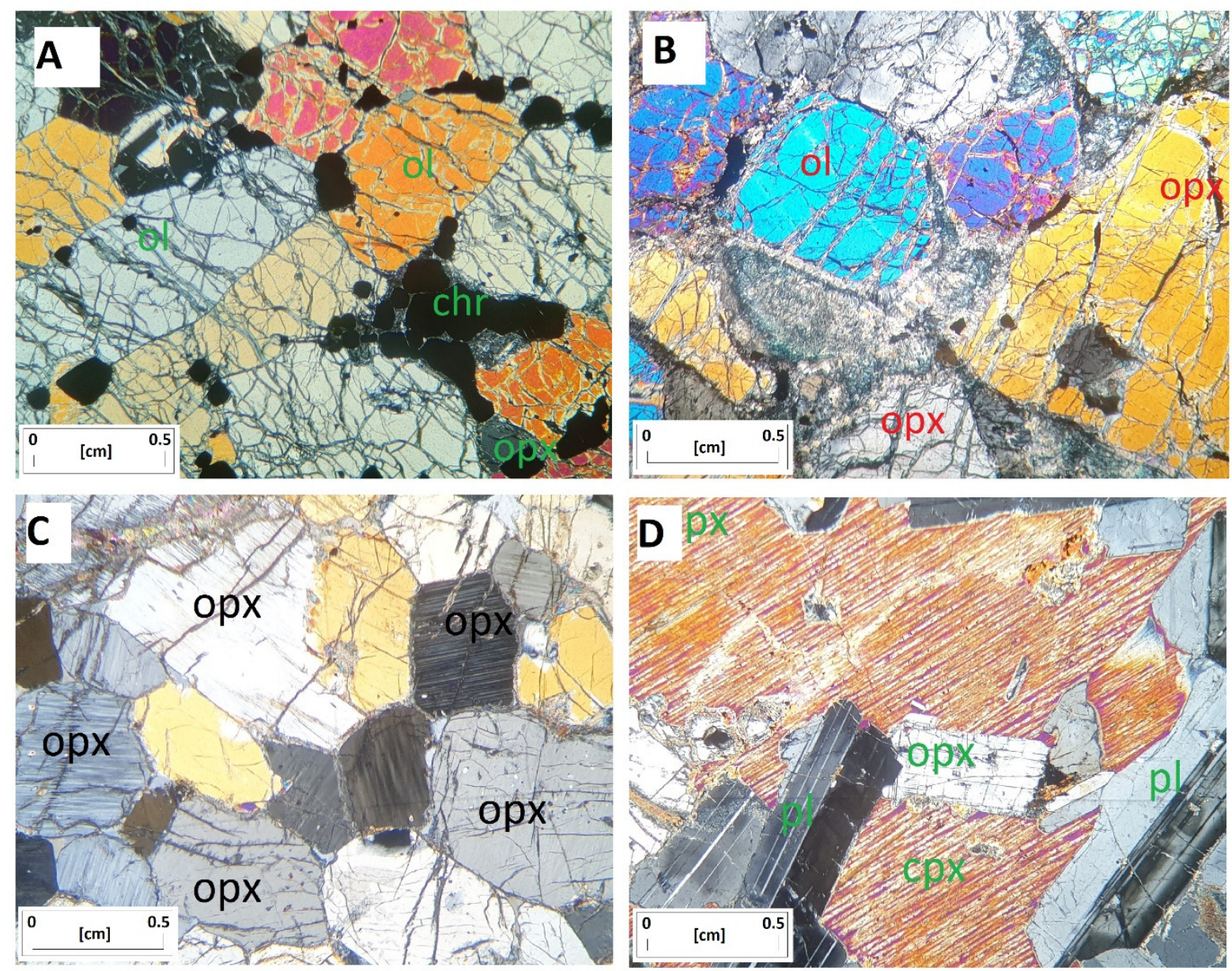

Figure 3. Examples of typical rocks from Moncheplutonu. (A) Dunite. (B) Harzburgite. (C) Orthopyroxenite. (D) Gabbronorite. Abbreviations: opx -orthopyroxene, cpx—clinopyroxene, ol—olivine, chr—chromite, pl—plagioclase.

Harzburgites (samples 05MON19, 16MON17, 38MON16, 45MON16, and 29MON17) are exposed in the Kumuzhia region, in the critical zones of the western Sopcha and Nyud horizons. They are gray-green rocks with a coarse crystalline, and very coarse crystalline structure, and a dense, chaotic, sometimes porous, lumpy texture. The background of these rocks is formed by olivine and orthopyroxene, as well as admixtures of chromite, and minor sulfides. Orthopyroxene forms large xenomorphic crystals, reaching several $\mathrm{mm}$ in length. In the spaces between these crystals, clinopyroxene, as well as titanite, a few plagioclases, and phlogopite are found (Figure 3B). Besides them, peridot is visible, usually showing a varying degree of advanced secondary processes, sometimes surrounded by a reaction corona made of serpentine, talc, and phlogopite. Its amount in the rocks in question varies, 
sometimes increasing significantly (03MON15). In the Nyud region, ilmenite, and biotite have been found in this type of rock.

Plagioharzburgite (08MON17, 56MON17, 81MON17) occurs in the Dunite Block, the western slopes of Traviannaya, and in Nyud. These are gray rocks, with a coarse crystalline structure, and a dense, random texture, sometimes porphyry. The olivine in these rocks shows lattice deformations (anomalous wavy dimming), accompanied by single phlogopite lamellae pressed between the minerals. Orthopyroxene in the rock constitutes a significant proportion of female components, oval crystals forming in contact with each other. Plagioclase can be seen between the femic phases, forming single irregular crystals pressed into the rock background. They are accompanied by single ore minerals, such as chromite, sulfides, and clinopyroxene.

The olivine plagiarists (84MON17 and 07MON18) are exposed in the Traviannaya massif. These are rocks with a coarse crystalline structure, sometimes very coarse, these structures taking the form of accumulations of large, greyish-green crystals composed of thick crystalline orthopyroxene, accompanied by olivine and minor clinopyroxene. Some orthopyroxene crystals are much larger than the other phases, showing deformations while darkening in wavy lines. Olivine is usually serpentinized. Next to it, there are magnetite infusions, and phlogopite, and chromite crystals in the form of single crystals located in the vicinity. Clinopyroxene is crystallized in the spaces between the orthopyroxenes and has strongly developed boundaries. Sometimes these rocks contain plagioclases, crystallizing between femic minerals. Sulfides are also common in these rocks.

Massive orthopyroxenites (66MON17, 67MON17, 39MON16, and 43MON16) are exposed in the eastern part of Traviannaya, in the Nittis, and Sopcha regions. They are greyish-greenish-colored rocks with a coarse-crystalline structure, a dense, random texture, with orthopyroxene constituting the background of the rock. It is accompanied by clinopyroxene, sulfides, actinolite, tremolite, talc, and magnetite (Figure 3C). Orthopyroxene usually takes the form of oval crystals of varying sizes in tight contact with each other (Figure 3C). Sometimes chromite is involved in the background of these minerals. Pseudo-olivine pseudomorphoses are composed of serpentine group minerals, and actinolite, tremolite, epidote, and talc may be present. In the area of Nittis, and the northern slopes of Sopch, there are varieties (29MON16 and 31MON19) in which small plagioclase crystals can be seen among the orthopyroxene minerals.

In the area of the Kumuzhia massif and the western slopes of Sopcha and Nittis (critical horizon), olivine orthopyroxenites (18MON19, 42MON16, 44MON16, and 04MON19) are found. They are usually gray-greenish-colored rocks with a coarse crystalline structure, and a dense, random texture. Orthopyroxene forms large crystals compacted with each other and constitutes the dominant phase in these rocks. It is accompanied by olivine, sometimes much larger than the surrounding orthopyroxene. In some rocks, it is heavily serpentinized, with visible talc and phlogopite. In other varieties (from Nittis) very small plagioclase crystals can also be seen. In places where the plagioclase meets the olivine, reactionary crowns made of serpentinite, phlogopite, and talc are visible also in the fracture zone of this mineral. Small amounts of chlorite were also noticed in the rock.

In the tectonic zones of the Kumuzhia Massif, a breccia of olivine pyroxenite (07MON19) cemented with hematite and sulfides were found. It is made of crushed orthopyroxene and olivine. Apart from these minerals, sometimes there is also chromite and diopside. Olivines show varying degrees of serpentinization. They are accompanied by talc, carbonates, iron oxides, and hydroxides. Sulfides in this scale are represented mainly by chalcopyrite, and, to a lesser extent, sphalerite, accompanied by hematite.

The burrows occurring in the Nyud and Poaz massifs (61MON17, 24MON17) are gray and gray-red rocks with a coarse-crystalline structure, and a dense, chaotic texture. They are made of plagioclase plaques, which form the offer structure and fill the background of the rock. In their vicinity is orthopyroxene, which usually forms large, oval-shaped crystals. Usually, it is cracked, and at the borders you can see talc and serpentine. In their vicinity, olivine crystals of various sizes may be present. In olivine varieties, it forms large crystals 
which give the rock an ophthalmic texture; in other cases, it may be present as small crystals. In addition to these minerals, you can sometimes see individual crystals of clinopyroxene, which usually have extensive boundaries. Biotite, ilmenite, pentlandite, apatite, as well as zircon, chloro-apatite, and fluorite, may be present as accessories. Gabbronorite was found in the transition zone between peridotites, and orthopyroxenites in Nyud (07MON17) and Poaz (58MON17). These are dark green rocks with a coarse crystalline structure and an ophthalmic texture. In these rocks, the background is composed of polysynthetically twin plaques of plagioclases (Figure 3D). Apart from these minerals, large, rounded orthopyroxene crystals were found, often cracked, with talc and serpentine visible on their borders, in addition to which there is clinopyroxene, sometimes with crystals up to $1 \mathrm{~cm}$ in size, strongly frayed, binding orthopyroxene and occurring between plagioclases. Sometimes these minerals are accompanied by single phlogopite plates, actinolite, and epidote, and relics of tiny olivine crystals. Ilmenite and magnetite are visible in the rock. In addition, in the area of contact with the rocks of the "critical horizon" of Nyud, there is a mineralized gabbronorite (15MON17) with visible sulfides represented by chalcopyrite, pyrite, pyrrhotite, and pentlandite.

\subsection{Rock-Forming Minerals Characteristic}

In the Monchepluton intrusion rocks that have been discussed, the rock-forming minerals are olivine, orthopyroxene, clinopyroxene, and plagioclase. These minerals are found in virtually all massifs of this intrusion. Depending on the type of rocks, they are a dominant or accessory component-a factor which influences their shape. Secondary processes taking place in these rocks with varying intensity also caused further changes in these minerals, which were reflected in their differentiation within the entire intrusion, as well as in individual massifs and rocks.

Olivine in ultra-basic rocks is very diverse. In rocks in which it predominates, it forms large, oval crystals in contact with each other. In other peridotite formations, it usually forms euhedral large crystals, sometimes subject to secondary processes. In these rocks, we can also see olivine crystals subject to mechanical deformation. The degree of advancement of olivine corrosion depends on the type of rock and its location in the massif. The most advanced secondary processes are located in tectonic zones, and at the junction of various rocks forming the so-called critical horizons. There, olivine is strongly changed (Figure $4 \mathrm{~A}-\mathrm{C}$ ), and around it there are reactive crowns made of serpentinite, talc, tremolite, and, though less often, phlogopite. In gabbro rocks, olivine occurs in varying proportions, sometimes forming large crystals in olivine holes. In these rocks, it shows far more advanced corrosion processes, sometimes until completely replaced by secondary minerals that create pseudomorphoses. In the case of corroded crystals, their boundaries are strongly jagged.

Orthopyroxene, similarly to olivine in ultra-basic rocks, is a mineral with a different pattern of occurrence. In olivine cumulates it occupies a minor position, usually as an accessory mineral, small in size, coexisting with other phases. Sometimes, however, it forms crystals of considerable size, reaching a size of several centimeters, usually with strongly ragged borders, showing lattice deformations and secondary processes (e.g., in the Traviannaya region). In orthopyroxenites, it usually forms large but also to some extent differentiated crystals in contact with each other. Usually, they are round in shape, creating a rock background. Their boundaries are usually concave-convex, depending on the surroundings of these minerals. In gabbronorite formations, this mineral usually cooperates with other phases and has a diversified shape. It is often fractured, uralitized with numerous secondary phases appearing in its vicinity (Figure 4D-F). This influences the shape of its border, which is strongly developed in these rocks. 

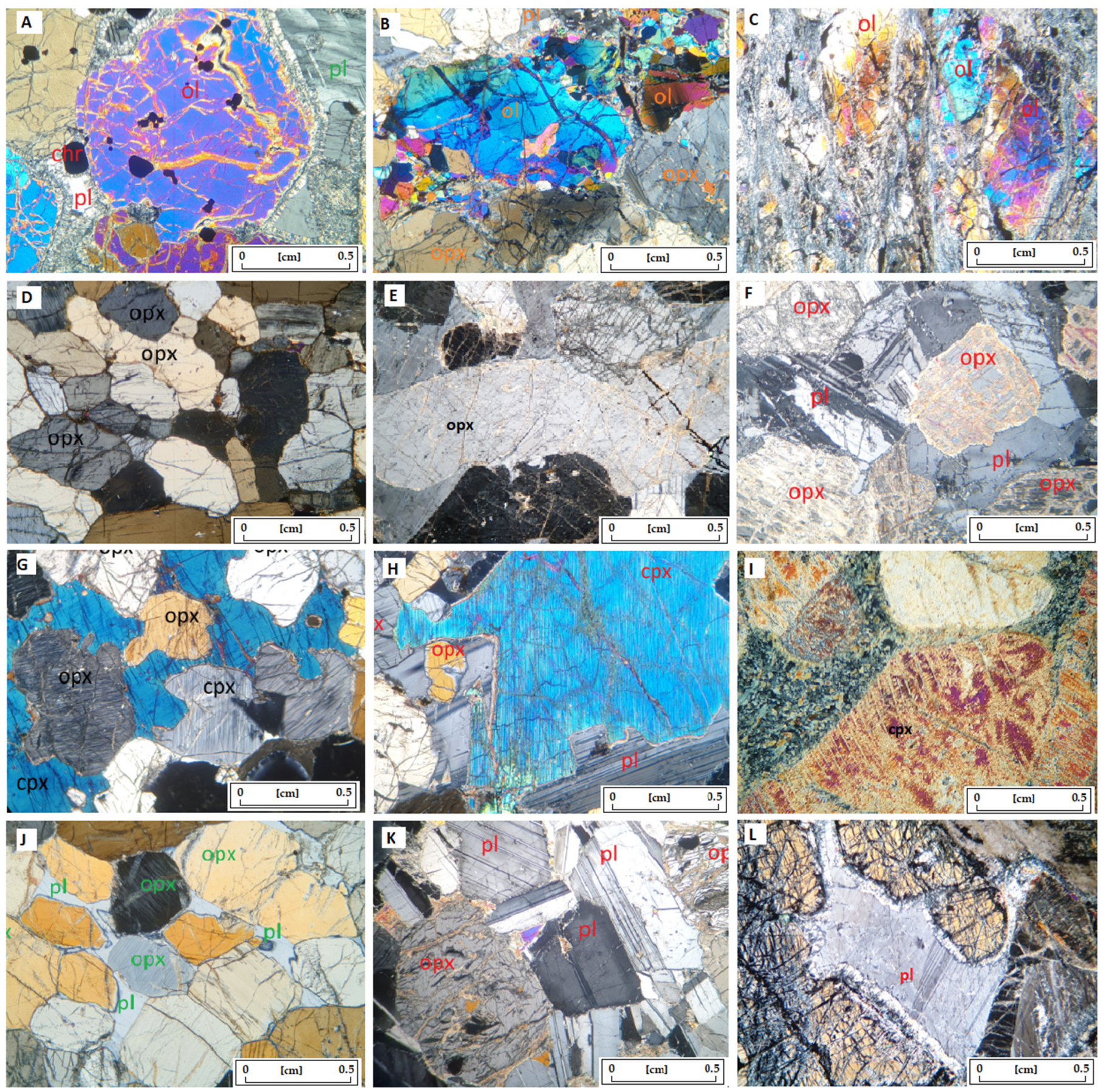

Figure 4. Different shapes of olivine. (A-C) Orthopyroxene. (D-F) Clinopyroxene. (G-I) Plagioclase. (J-L) Olivine co-occurring in dunite. (A) Euhedral olivine crystal. (B) Euhedral olivine crystal in harzburgite. (C) Melted olivine in myllonitized peridotite. (D) Orthopyroxene in orthopyroxenite. (E) Orthopyroxene in harzburgite. (F) Corroded orthopyroxene in norite. (G) Clinopyroxene in orthopyroxenite. (H) Clinopyroxene in norite. (I) Clinopyroxene in saussuritized gabbro. (J) Plagioclase in orthopyroxenite. (K) Plagioclase in norite (L) Plagioclase in plagioharzburgite. Abbreviations: opx—orthopyroxene, cpx—clinopyroxene, ol—olivine, chr—chromite, pl—plagioclase.

Clinopyroxene in ultrabasic formations is an accessory mineral, accompanying olivine and orthopyroxene, mainly in zones where these rocks are subject to secondary processes. When crystallizing in the spaces between other femic minerals in their corrosion zones, clinopyroxene usually has very extensive boundaries. The content of clinopyroxene increases significantly in gabbro rocks, where it is a rock-forming mineral. In gabbroid, clinopyroxene can occur both as a background mineral (gabbro, gabbronorites), and in 
an accessory or even relict form (meta-anorthosites; see Figure 4G,I). In gabbro rocks, the crystallizing clinopyroxene usually forms large crystals of various shapes. Due to secondary processes also taking place in these rocks, clinopyroxene is crushed, deformed, and uralized. This affects its boundaries, which are usually very diverse in these rocks.

Plagioclases in ultrabasic formations take the form of a small admixture in the zones of secondary processes in these rocks. Usually, small crystals surrounded by femic minerals crystallize there, often in the vicinity of the reaction crowns between these phases. In gabbroid rocks, they appear as rock-forming phases, usually as polysynthetic twins, forming an ophthalmic texture in the rock (Figure 4J-L). In these cases, they are highly differentiated, crystallizing in varying sizes depending on their location in the rock. Sometimes, however, they are also subject to secondary processes related to their sericitization, which also affects the nature of their boundaries.

\subsection{Fractal Analysis Results}

As a result of the research on rock-forming minerals in the above-mentioned tests, calculations were made for 190 selected minerals found in the rocks of Monchepluton. Their average results are presented in Table 2.

Table 2. Fractal dimension results calculated for individual types of minerals.

\begin{tabular}{|c|c|c|c|c|c|c|c|c|c|c|c|}
\hline \multirow{2}{*}{ Sample } & \multicolumn{4}{|c|}{ Fractal Analysis Results } & \multirow{2}{*}{ Massif } & \multirow{2}{*}{ Sample } & \multicolumn{4}{|c|}{ Fractal Analysis Results } & \multirow{2}{*}{ Massif } \\
\hline & ol & opx & cpx & pl & & & ol & opx & cpx & pl & \\
\hline 46MON17 & 1.81 & 1.75 & & 1.43 & Dunite Block & 40MON19 & 1.61 & & & & Sopcha N \\
\hline 52MON17 & 1.76 & 1.36 & & & Dunite Block & 38MON16 & 1.39 & 1.71 & 1.63 & & Sopcha W \\
\hline 02MON19 & 1.53 & 1.75 & 1.42 & 1.72 & Dunite Block & 39MON16 & & 1.74 & & 0.87 & Sopcha W \\
\hline 03MON19 & 1.63 & 1.70 & & 1.01 & Kumuzhia & 42MON16 & 1.71 & 1.77 & 1.54 & 1.10 & Sopcha W \\
\hline 04MON19 & 1.69 & 1.81 & 1.33 & & Kumuzhia & 43MON16 & & 1.72 & 1.26 & & Sopcha W \\
\hline 05MON19 & 1.67 & 1.64 & & & Kumuzhia & $44 \mathrm{MON} 16$ & 1.07 & 1.80 & 1.14 & & Sopcha W \\
\hline 07MON19 & 1.75 & 1.73 & 1.25 & 1.00 & Kumuzhia & 45MON16 & 1.72 & 1.69 & & & Sopcha W \\
\hline 18MON19 & 1.49 & 1.68 & 1.19 & 1.39 & Nittis & 08MON17 & & 1.79 & & 1.33 & Nyud \\
\hline 58MON17 & & 1.73 & 1.29 & 1.74 & Poaz & 09MON17 & & 1.69 & & 1.51 & Nyud \\
\hline 61MON17 & & & & 1.77 & Poaz & 14MON17 & 1.58 & 1.69 & 1.84 & 1.58 & Nyud \\
\hline 29MON17 & 1.50 & 1.75 & & & Sopcha E & 15MON17 & & 1.65 & 1.38 & 1.50 & Nyud \\
\hline 31MON17 & & 1.76 & 1.48 & 1.43 & Sopcha E & 16MON17 & 1.76 & & & & Nyud \\
\hline 32MON17 & & 1.67 & & 1.35 & Sopcha E & 20MON17 & 1.46 & 1.77 & 1.54 & 1.69 & Nyud \\
\hline 34MON17 & 1.54 & 1.72 & & 1.60 & Sopcha E & 22MON17 & & 1.73 & 1.39 & 1.78 & Nyud \\
\hline 38MON17 & 1.61 & 1.68 & & 1.15 & Sopcha E & 24MON17 & 1.64 & 1.70 & 1.32 & & Nyud \\
\hline 30MON17 & & 1.74 & 1.65 & 1.30 & Sopcha N & 01MON19 & 1.73 & 1.76 & & 1.74 & Traviannaya \\
\hline 31MON19 & 1.68 & 1.68 & & & Sopcha N & 07MON18 & 1.62 & 1.75 & 1.40 & & Traviannaya \\
\hline 32MON19 & & 1.75 & & 1.37 & Sopcha N & 67MON17 & & 1.75 & 1.27 & & Traviannaya \\
\hline 39MON19 & & 1.72 & & & Sopcha N & 84MON17 & 1.47 & 1.69 & 1.57 & 1.63 & Traviannaya \\
\hline
\end{tabular}

Abbreviations: ol—olivine, opx-orthopyroxene, cpx—clinopyroxene, pl—plagioclase.

Among the examined olivines, the crystals from the critical horizons of Sopcha and Nyud are characterized by the lowest fractal dimensions (Table 2, Figure 5A). There are olivine crystals existing as fresh, often euhedral minerals. The olivines in the Traviannaya rocks have slightly higher ratios, where they form rocks in which this mineral is admixed. These minerals show the highest fractal dimension for the rocks of the Dunite Block, where they are subject to various corrosive processes. Similarly, high fractal dimensions are characteristic of rocks from the Nyud, Kumuzha, and Traviannaya regions, which rocks show numerous secondary processes. 

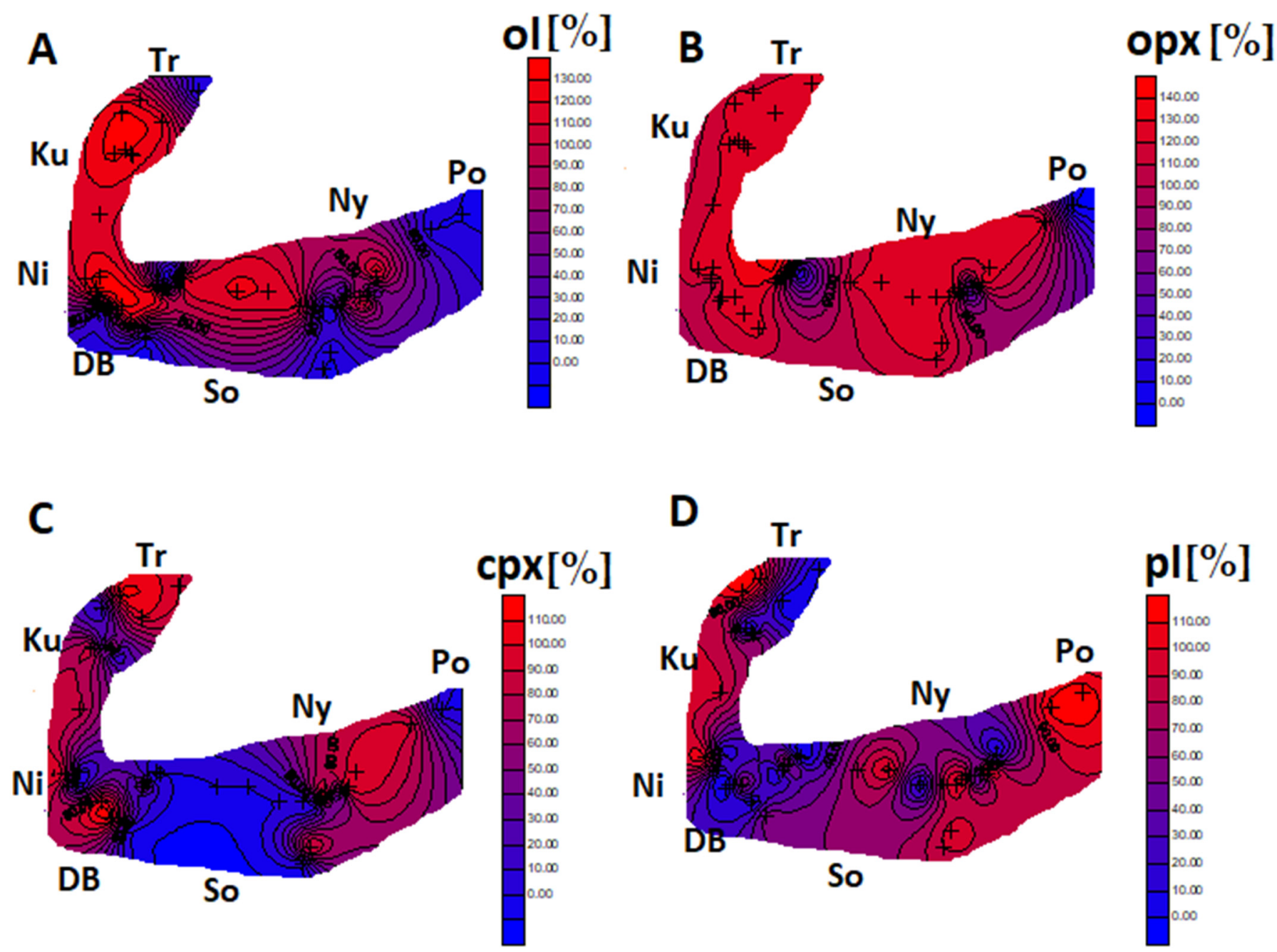

Figure 5. Maps of fractal dimension distribution for (A) olivines, (B) plagioclases, (C) orthopyroxenes, and (D) clinopyroxenes. Abbreviations: Tr—Traviannaya; Ku-Kumuzhia; Ni-Nittis; DB-Dunite Block; So-Sopcha; Ny-Nyud; Po-Poaz. The scale in figures represents values from 0 to more than $130 \%$, indicating the manner of complexity of the crystal boundary. A value of $100 \%$ is taken to be euhedral in shape; lower values indicate more spherical, simple forms, while higher values indicate strongly frayed crystals with an elaborate boundary. A value of $0 \%$ means there is no crystal in the rock sample under study.

In the case of orthopyroxenite, the orthopyroxene crystals of the Kumuzhia and Nyud massifs, and the eastern part of Sopcha, have the lowest fractal dimensions. In these rocks, the mineral usually has an anhedral shape, coexisting with itself to create the background. The highest fractal dimension is noted in those Nyud rivers where the corrosion processes of orthopyroxene are marked. It is usually crushed there, and is uralitized. Similarly, high fractal dimensions were noted for the Poaz gabbronorite. However, in the case of this mineral, it has very different fractal dimensions depending on the secondary processes that contributed to its corrosion, regardless of the massif in which it occurs. More often, it occurs on tectonic zones, where the impact of hydrothermal processes is observed (Table 2, Figure 5B).

The clinopyroxene in these rocks also varies widely (Table 2, Figure 5C). In the Nittis Formations, there are relatively well-formed anhedral crystals of clinopyroxene, while in the rocks of Sopcha and Kumuzhia, which are subject to secondary processes, this mineral usually constitutes a small admixture, because it also has a low fractal dimension factor. The highest index of this mineral was recorded for the rocks of Nyud, Poaz, and Sopcha. In gabbroid, clinopyroxene crystals undergo uralitization, which influences their border 
shape. In turn, in the Sopcha rocks in tectonic zones where clinopyroxene recrystallizes (usually including orthopyroxene), it has extensive boundaries due to its nature. The situation is similar in the case of plagioclases. In the rocks of Kumuzhia and Sopcha, where the secondary plagioclase occurs only in the form of small and few accessory crystals, it is usually limited by other minerals, which take the shape of small intrusions between these phases. Plagioclase minerals from the Poaz massif and Nyud have the highest fractal dimension factor, where plagioclase forms large plaques of different sizes, sometimes sericitized (Table 2, Figure 5D). In the plagioharzburgites of the Traviannaya tectonic zones, plagioclases are also corroded, occurring in the vicinity of the crowns of reaction femoral minerals. This differentiation is illustrated on the maps presented in Figure 5.

Comparing the fractal dimension results obtained with the textural features of individual minerals that have been discussed, a certain dependence is visible, related to their character in rocks. Where secondary features appear, the corrosion of these minerals causes their boundaries to expand, and this is well illustrated by the data. This fractal dimension can be determined by examining a particular mineral and defining its limit values. This means that by knowing these data, it is possible to determine the advancement of secondary processes in the massif based on the mentioned fractal factor. Thus, in the case of olivine, the fractal dimension factor in Monchepluton rocks can be correlated as 1.4 for fresh, non-corroded olivine, having a euhedral shape. Below this value, olivines have a more spherical shape, e.g., in cumulates, where they are a rock-forming mineral. Above the value of 1.6, it can be determined that this mineral is already corroded. In this case, where this value appears on the map, it can be considered that the rocks show traces of secondary processes. For orthopyroxene, the mean value for euhedral crystals may be used as a factor of 1.6. Above this value, the increase in the fractal dimension should be correlated with the corrosion of this mineral, i.e., with the impact of secondary processes. For corroded orthopyroxene, the value limit are 1.7 and higher. Clinopyroxene in Monchepluton rocks is a mineral of a more diverse nature. As a slight admixture, it can occur in ultra-basic rocks, such as dunites and Harzburgites, subject to secondary processes. In these rocks, the mineral forms small crystals and has a low fractal dimension value close to 1.2. Clinopyroxene, which has more extensive boundaries, can also be described as a secondary mineral, and it will have a fractal dimension factor above 1.4. In extreme values, the uralitized clinopyroxene may reach a factor above 1.8. Euhedral crystals in gabbronorite rocks, according to the measurements made, have a fractal dimension between 1.3 and 1.4. In the case of plagioclases, the plaques of these crystals usually reach a factor of 1.5. Minerals, which are usually found as small inclusions in rocks subject to secondary processes have relatively low values (1.3), while minerals subject to sericitization have a more high value (1.6-1.8).

\section{Discussion}

By analyzing the correlations of these minerals based on their fractal dimension factors (Figure 6), some trends can be plotted. Where the fractal dimension factor of olivine increases, orthopyroxene also increases (Figure 7A), while in the olivine-orthopyroxene pair, olivine usually has a factor much higher than orthopyroxene, which shows the corrosion of this mineral. Olivine corrodes relatively quickly; therefore, olivine is usually an admixture in orthopyroxene rocks and already exhibits corrosion properties. In the case of the olivine-clinopyroxene and olivine-plagioclase pairs, the trends are decreasing (Figure $7 \mathrm{~B}, \mathrm{C}$ ). Wherever olivine has a high fractal dimension factor, clinopyroxene and plagioclase are generally present as secondary minerals, with a small fractal factor, and this affects the correlation of these factors. In gabbro rocks where clinopyroxene and plagioclase are more abundant, olivine usually still has a high fractal dimension, but lower than in the previous case. It should also be noted that the tested dunite rocks were usually heavily serpentinized, which affects the result of this correlation. The correlation analysis for the orthopyroxene-clinopyroxene pair (Figure 7D) is also increasing, although it is much stronger for orthopyroxene, because usually, where clinopyroxene appears, the first mineral 
shows the features of secondary processes. In both cases, they deepen in rocks subject to corrosion of these minerals. The correlation analysis for orthopyroxene-plagioclase is similar (Figure 7E).

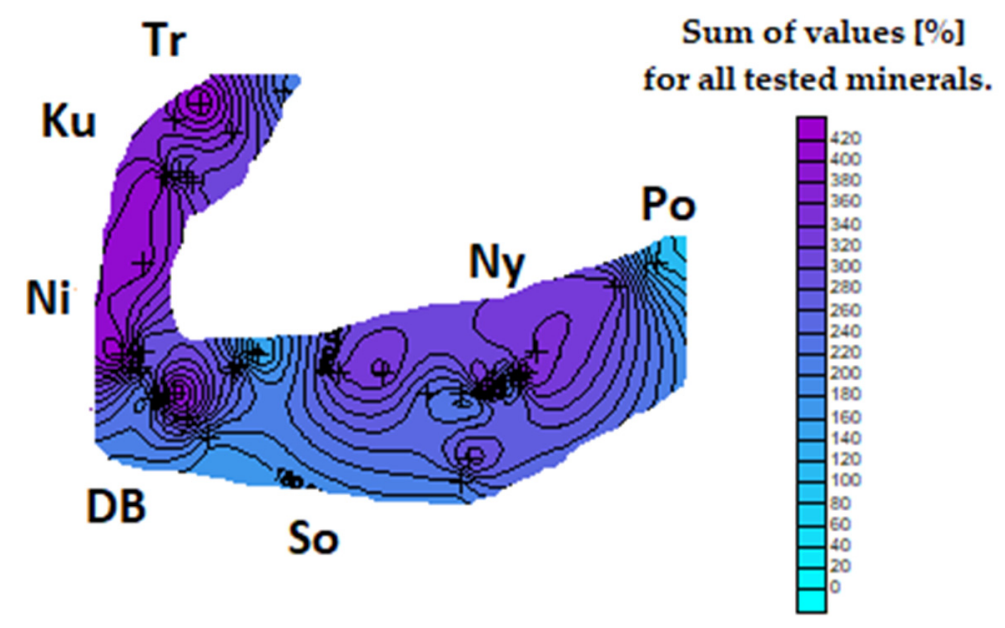

Figure 6. Map showing the \% sum of the fractal ratio for olivine, orthopyroxene, clinopyroxene, and plagioclase in Monchepluton. Abbreviations: $\mathrm{Tr}$ - Traviannaya; $\mathrm{Ku}-\mathrm{Kumuzhia}$; Ni-Nittis; DB-Dunite Block; So-Sopcha; Ny-Nyud; Po-Poaz.

\section{A}

ol
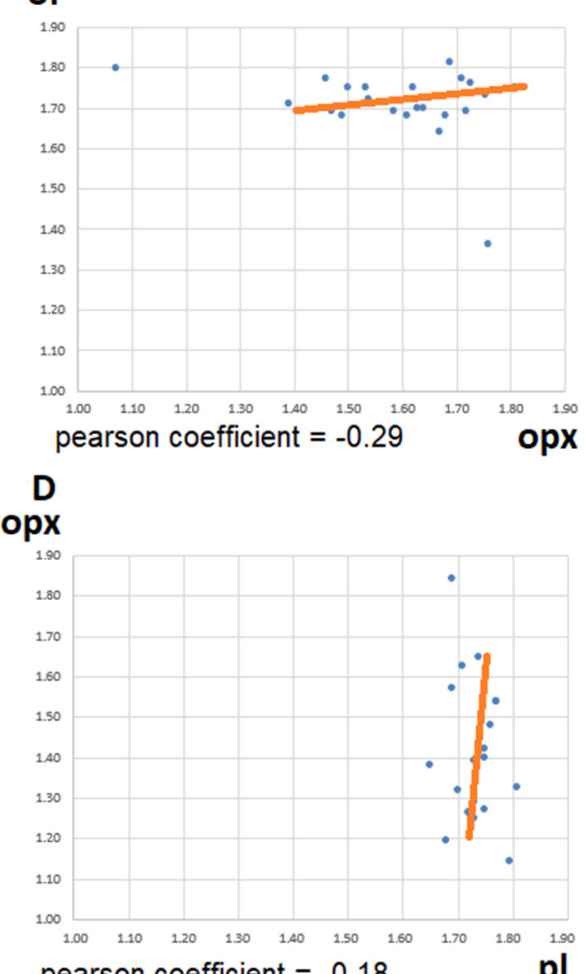

pearson coefficient $=-0.18$
B

ol

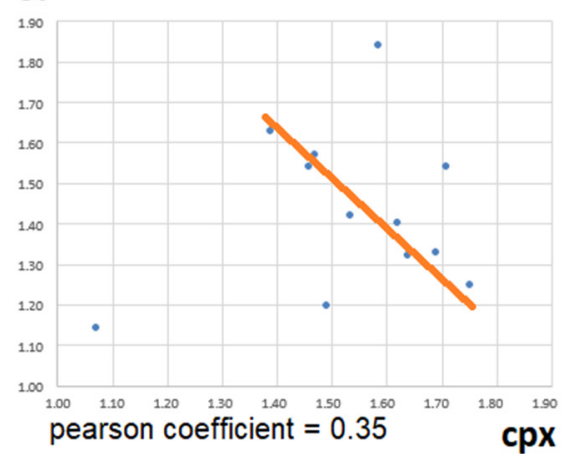

\section{$E$}

opx

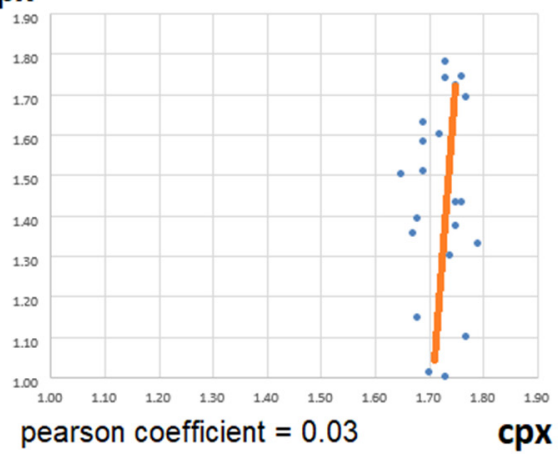

C

ol

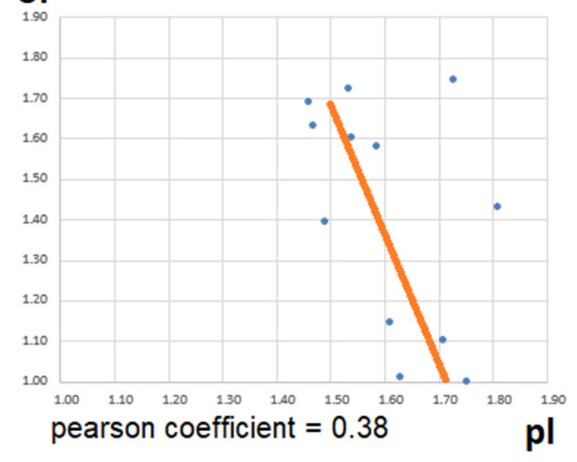

$F$

cpx

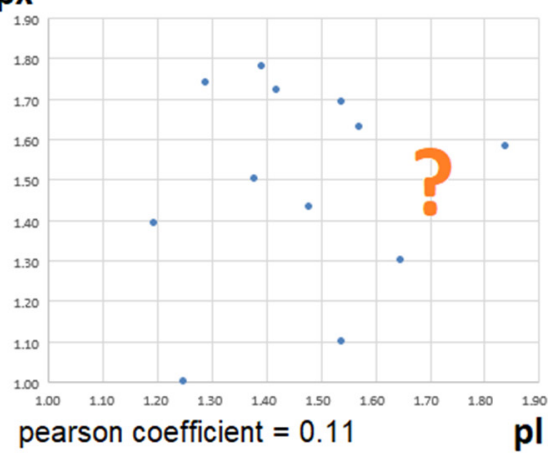

Figure 7. Correlation of the fractal dimension for couples: olivine—orthopyroxene (A), olivine—clinopyroxenes (B), olivineplagioclase (C), orthopyroxene-plagioclase (D), orthopyroxene-clinopyroxenes (E), orthopyroxene-plagioclase (F). Abbreviations: ol—olivine; opx—orthopyroxene; cpx—clinopyroxene; pl—plagioclase.

In these rocks, plagioclase appears as an admixture in pyroxenites as a secondary mineral; therefore, as a rule, orthopyroxene already shows signs of corrosion of the mineral there. In gabbro rocks where this plagioclase is also sericitized, orthopyroxene is corroded. 
The correlation for the clinopyroxene-plagioclase pair (Figure 7F) is not reliable enough to perform an analysis - the number of points is small and they are scattered. Based on microscopic observations, it can be shown that where these minerals are an admixture, they may show a small fractal dimension factor, but in the case of clinopyroxene regrowing orthopyroxene in rocks subject to secondary processes, this mineral has high fractal dimension factors, while plagioclase may still appear as a slight admixture. On the other hand, clinopyroxene and plagioclase are subject to corrosion in the saussuritized gabbro rocks. Both minerals have high fractal dimensions there.

By analyzing the correlations shown in the results, it is possible to try to draw a map in which the limit values for the four minerals in question will be overlaid, showing the image of their occurrence (Figure 6). The mean values for euhedral minerals were taken as $100 \%$ for each. (As discussed above, minerals having a higher index have values exceeding $100 \%$, and no data for the mineral is marked as $0 \%$ ). A Pearson coefficient for the measured values is relatively weak, although it is much stronger in the comparison of olivine with ortho- and clinopyroxene. This may be due to the small amount of data, but the effect may also be related to factors on which the shape of the pyroxenes in question depends.

Analyzing the map in Figure 6, it can be concluded that the western massifs (NKT) are relatively significantly changed, where among ultra-basic rocks many secondary processes related to the tectonics of these blocks and the influence of hydrothermal vein processes are noticeable. The zone of the Dunite Block with olivine-chromite accumulations, as well as the Western Sopcha Slopes, where the rocks of the so-called critical horizon are in contact with each other, has also been relatively changed. A certain incidence of secondary processes is also reflected in the "Terrace" critical zone for the Nyud Massif. According to the above data, relatively speaking, the least changed are the northern Sopcha massif and the Poaz massif.

When examining the dependencies shown in the results, it must be stated that they require must be carefully examined on a case-by-case basis and cannot be interpolated to other rocks and massifs without knowledge of their petrography. This is because the minerals described in different rocks may have a different character. The crystallization phase in these rocks could be different, and secondary processes could take place in different intensities and orders. This means that character of mineral in studied rocks cannot be precisely characterized based on a fractal dimension result. This is the case, for example, in the case of plagioclases, which in Monchepluton occurs in ultrabasic rocks as a secondary, accessory phase, and, despite the low fractal dimension factor, their occurrence cannot be correlated with the primary crystallization of the minerals that make up these rocks. Therefore, before carrying out the analysis in question, one should first familiarize oneself with the petrographic properties of individual minerals. However, undoubtedly a positive feature of the discussed method is the possibility of carrying out reproducible results, determining the degree of corrosion of the mineral by means of conversion to the percentage scale.

The limitation of this method is the fact that this dimension shows only the development of the mineral boundary, not a specific shape and character concerning the crystal axis of crystallization. This should be borne in mind when interpreting these data.

\section{Conclusions}

The Monchepluton massif in question is the Paleoproterozoic Layereg PGE intrusion, composed of ultra-basic and basic rocks. The minerals of olivine, orthopyroxene, clinopyroxene, and plagioclase in this massif are rock-forming. In ultra-basic rocks, clinopyroxene and plagioclase are an admixture and are an indicator of secondary processes taking place in these rocks. In gabbro rocks, olivine usually occurs as an accessory mineral, and orthopyroxene coexists with clinopyroxene and plagioclase.

Based on the analysis of its fractal dimension, it is possible to convert the nature of the limits of a mineral into a numerical fractal dimension and correlate it with the role of the mineral in this scale. The fractal dimension factor can precisely indicate the nature of the 
crystal boundary for which it was calculated, and on this basis it is possible to precisely indicate the variability of this index by correlating the studied rocks with their presence in the intrusion plan.

By creating a map of the distribution of the fractal dimension as a function of the location of the tested samples, it is possible to visualize and trace its changes. On this basis, knowing the limit values, it is possible to indicate those zones of rock occurrence where they are subject to secondary processes. These dependencies are the more important the more samples are put on the map.

The interpretation of the crystallization processes of individual minerals in the studied massif depends on the function of the analyzed phases in the rocks present there.

Due to the specificity of crystallization of minerals, this method cannot be simply extrapolated, and always requires great care in interpretation.

Author Contributions: Conceptualization, M.H.; methodology, M.H.; software, K.S.; validation, M.H. and K.S.; formal analysis, K.S.; investigation, M.H.; resources, M.H.; data curation, M.H.; writingoriginal draft preparation, writing-review and editing, visualization, supervision, M.H.; project administration, M.H. All authors have read and agreed to the published version of the manuscript.

Funding: This research received no external funding.

Data Availability Statement: Not applicable.

Conflicts of Interest: The authors declare no conflict of interest.

\section{References}

1. Chen, T.L.; Shi, Z.L.; Wen, A.; Yan, D.; Gou, J.; Chen, J.; Liu, Y.; Chen, R. Multifractal characteristics, and spatial variability of soil particle-size distribution in different 1 , and use patterns in a small catchment of the Three Gorges Reservoir Region. China J. Mt. Sci. 2021, 18, 111-125. [CrossRef]

2. Gulbin, Y.L.; Evangulova, E.B. Morphometry of Quartz Aggregates in Granites: Fractal Images Referring to Nucleation, and Growth Processes. Math. Geol. 2003, 35, 819-833. [CrossRef]

3. Kincal, C.; Koca, M.Y.; Ozden, G.; Demirbasa, N. Fractal parameter approach on weathering grade determination of Cesme (Izmir, Turkey) tuffs. Bull. Eng. Geol. Environ. 2010, 69, 617-629. [CrossRef]

4. Lehmann, P.; Stahla, M.; Papritz, A.; Gygi, A.; Fluher, H. A Fractal Approach to Model Soil Structure, and to Calculate Thermal Conductivity of Soils. Transp. Porous Media 2003, 52, 313-332. [CrossRef]

5. Martin, M.A.; Reyes, M. A Fractal Interaction Model for Winding Paths through Complex Distributions: Application to Soil Drainage Networks. Pure Appl. Geophys. 2008, 165, 1153-1165. [CrossRef]

6. Mohammadi, A.; Khakzad, A.; Omran, N.R.; Mahvi, M.R.; Moarefvand, P.; Afzal, P. Application of number-size (N-S) fractal model for separation of mineralized zones in Dareh-Ashki gold deposit, Muteh Complex. Central Iran. Arab J Geosci. 2013, 6, 4387-4398. [CrossRef]

7. Zhengli, M.; Jian Qing, L.; Yang, B. The geochemical multi-fractal characteristics, and mineralization of the Dehelongwa copper-gold deposit. Chin. J. Geochem. 2014, 33, 280-288. [CrossRef]

8. Słaby, E.; Domonik, A.; Śmigielski, M.; Majzner, K.; Motuza, G.; Goetze, J.; Simon, K.; Moszumańska, I.; Kruszewski, Ł.; Rydelek, P. Protomylonite evolution potentially revealed by the 3D depiction, and fractal analysis of chemical data from a feldspar. Contrib. Miner. Petrol. 2014, 167, 995. [CrossRef]

9. Gerig, A.; Kruhl, J.H.; Caggianelli, A. Quantification of Flow Patterns in Sheared Tonalite Crystal-melt Mush: Application of Fractal-geometry Methods. J. Geol. Soc. India 2010, 75, 210-224. [CrossRef]

10. Singh, A.K.; Upadhyay, D.; Pruseth, K.L.; Mezger, K.; Nanda, J.K.; Maiti, S.; Saha, D. Shock Metamorphic Features in the Archean Simlipal Complex, Singhbhum Craton, Eastern India: Possible Remnant of a Large Impact Structure. J. Geol. Soc. India 2021, 97, 35-47. [CrossRef]

11. Voitsekhovsky, Y.L.; Shpachenko, A.K.; Skiba, V.I. Cell-zonal textures of tinguaites from the Kola Peninsula. Geol. Rundsch. 1997, 86, 531-538. [CrossRef]

12. Zheru, Z.; Huahi, M.; Cheng, Q. Fractal Geometry of Element Distribution on Mineral Surfaces. Math. Geol. 2001, 33, 2. [CrossRef]

13. Huber, M. Evolution of the Kola-Lapland Mobile Belt on the Example of Platinum-Bearing Paleoproterozoic Layered Monchepluton Intrusion; Maria Curie-Sklodowska University: Lublin, Poland, 2021.

14. Mitrofanov, A.F. Geological Characteristics of the Kola Peninsula; Kola Scientific Center, Russian Academy of Sciences: Apatity, Russia, 2000; p. 166.

15. Sharkov, E.V. Formation of Layered Intrusions, and Their Ore Mineralization; Moscov Scientific World: Moscow, Russia, 2006 ; p. 368.

16. Bayanova, T.B. Age of Benchmark Geological Complexes of the Kola Region, and Magmatism Processes Action; Sankt Petersburg: Nauka, Russia, 2004; p. 174. 
17. Bayanova, T.; Korchagin, A.; Mitrofanov, A.; Serov, P.; Ekimova, N.; Nitkina, E.; Kamensky, I.; Elizarov, D.; Huber, M. Long-Lived Mantle Plume, and Polyphase Evolution of Palaeoproterozoic PGE Intrusions in the Fennoscandian Shield. Minerals 2019, 9, 59. [CrossRef]

18. Pozhylienko, V.I.; Gavrilienko, B.V.; Zhirov, D.V.; Zhabin, S.V. Geology of the Ore Regions in Murmansk District; Kola Scientific Center, Russian Academy of Sciences: Apatity, Russia, 2002; p. 360.

19. Hałas, S.; Huber, M.; Piestrzyński, A. Petrology of gabbroid, and isotope signature of sulfide mineralization from Fedorov-Pansky layered mafic intrusion, Kola Peninsula, Russia. Geochronometria 2009, 33, 19-22.

20. Huber, M. Dynamics of metamorphism processes by the fractal textures analysis of garnets, amphibole, and pyroxenes of Lapland Granulite Belt, Kola Peninsula. J. Biol. Earth Sci. 2012, 2, 50-55.

21. Lubnina, N.V.; Pasenko, A.M.; Novikova, M.A.; Bubnov, A.Y. The East European Craton at the End of the Paleoproterozoic: A New Paleomagnetic Pole of 1.79-1.75 Ga. Mosc. Univ. Geol. Bull. 2016, 71, 8-17. [CrossRef]

22. Rundkvist, T.V.; Mokrushin, A.V.; Huber, M.; Pripachkin, P.V.; Bazai, A.V.; Miroshnikova, Y.A. New data on the composition of chrome spinellids in the rocks of the southeastern of the Early Proterozoic Monchegorsk complex (Kola region). Bull. Kola Sci. Cent. Russ. Acad. Sci. 2018, 1, 50-62. [CrossRef]

23. Arzamastsev, A.A.; Fedotov, Z.A.; Arzamastseva, L.V. Dyke Magmatism of the N-E of Baltic Shield; Sankt Petersburg: Nauka, Russia, $2009 ;$ p. 383.

24. Baltybaev, S.K. Svecofennian Orogen of the Fennoscandian Shield: Compositional, and Isotopic Zoning, and Its Tectonic Interpretation. Geotectonics 2013, 47, 452-464. [CrossRef]

25. Mitrofanov, F.P.; Smolkin, V.F. Stratified Intrusions of the Monchegorsk Ore Region: Petrology, Mineralization, Isotopes, Deep Structure. In 2 Parts; Kola Scientific Center, Russian Academy of Sciences: Apatity, Russia, 2004; p. 344.

26. Miyashiro, A. Metamorphic Petrology; CRC Press: Boca Raton, FL, USA, 1994; p. 416.

27. Petigen, H.O.; Jürgens, H.; Saupe, D. Fractals for the Classroom; Springer: New York, NY, USA, 1992; p. 546. 